\title{
Development of Spinning Media as an Information Service to Enhance Students Career Planning
}

\author{
Hardiyansyah Masya* \\ Guidance and Counseling \\ Raden Intan Islamic State University \\ Lampung, Indonesia \\ hardiyansyah.masya@ radenintan.ac.id* \\ Permatasari \\ Guidance and Counseling \\ Raden Intan Islamic State University \\ Lampung, Indonesia \\ permataonte193@gmail.com
}

\author{
Tri Dewantari \\ Guidance and Counseling \\ Raden Intan Islamic State University \\ Lampung, Indonesia \\ dewantaritri@gmail.com \\ Veni Purnamasari \\ Guidance and Counseling \\ Raden Intan Islamic State University \\ Lampung, Indonesia \\ venipurnamasari649@yahoo.com
}

\author{
Indah Fajriani \\ Psychology \\ Raden Intan Islamic State University \\ Lampung, Indonesia \\ indah_fajriani@radenintan.ac.id \\ Abdul Aziz \\ Guidance and Counseling \\ Raden Intan Islamic State University \\ Lampung, Indonesia \\ aazizabdul1@gmail.com
}

\begin{abstract}
Career planning is one of the tasks of adolescent development. However, not all students in high schools have good career planning, there are students who experiencing confusion when asked about the continuation of school to university degree, and future career. To overcome the problems that occur, it is necessary to provide service delivery techniques that can help students improve their career planning skills. Media Spinning as an information service can help individuals in adding information related to the world of career understanding and career development in accordance with their abilities.
\end{abstract}

Keywords—spinning media, information counseling service, career planning

\section{INTRODUCTION}

Career is an important thing in human life. Every human being will feel confused when he does not know his career goals or career continuity, causing him to become unemployed or work but not in accordance with his potential. One of the things you can do to avoid career confusion is to have career planning. Career planning possessed by students is useful for the selection of further study types, and the selection of work plans. According to Simamora career planning is a process in deciding the goals to be achieved during the coming time period and designing various ways that will be done to help achieve these goals [1].

Achieving these goals requires careful career planning. Career planning can begin when an individual gets an education at school. In this case, while in high school students are already faced with career selection. The high school students are in adolescent development. Adolescence is a time of transition from childhood to adulthood. In adolescence, students have been required to determine future careers. According to Super, Crites, Hummel, Moser, Overstreet, \& Warnath [2] career development in high school is an exploration stage that starts at the age of 15 to 24 years. At this stage adolescents develop themselves and the world of work and try new roles in terms of career maturity. This is in line with the opinion of Havighurst [3] which explains that "in adolescence there are several development tasks that must be completed, one of the developmental tasks that must be achieved is choosing and preparing for a career.

But in reality there are still students who have not been able to determine the continuation of his career and the future of his career. This is an evident derived from research conducted by Pujiastuti [4] which obtained data that $81.58 \%$ of 38 students in SMA Negeri 23 Bandung had low career planning. This is in line with Atmaja's research [5] which obtained data that there were 12 students in MAN Wonokromo Bantul Yogyakarta who had low career planning. This is indicated by the lack of student interest to continue their studies and prefer to work. But will feel confused and unable to answer when asked the question "where will work and what work".

Career planning problems also occur in high schools in Bandar Lampung, of the 26 students there are only 12 students who already have careful self-planning. This is marked by students who tend to feel confused when asked where to continue their studies or where to work. Based on the results of the interview this is due to the lack of student information which is one of the obstacles in determining the direction of choice for further stage or career. Especially those related to tertiary institutions so that students feel uneasy to form it.

Information services related to career planning are very important for students. It is hoped that students who obtain career services not only get information about the career world but also about their career related understanding and how students can develop careers in accordance with their abilities. Based on the problems that occur, it requires techniques that can help students overcome the ability of students' career planning. One way that can be done is to use media spinning as an information service. 


\section{METHOD}

The method used in this study is research and development $(\mathrm{R} \& \mathrm{D})$. This study aims to produce products and test the effectiveness of the product. The model used in this study is Borg and Gall, which has 10 stages [6], namely 1) gathering information or preliminary data, 2) planning, 3) developing the initial form of the product, 4) initial field testing, 5) major product revisions, 6) main field tests, 7) operational product revisions, 8) operational field tests, 9) final product revisions, 10) dissemination and implementation. The research was not carried out until the 10th stage because it was adjusted to the objectives of the researcher, so the stage carried out in this study was adjusted to the needs of the researcher. The development steps used are explained in Figure1 below.

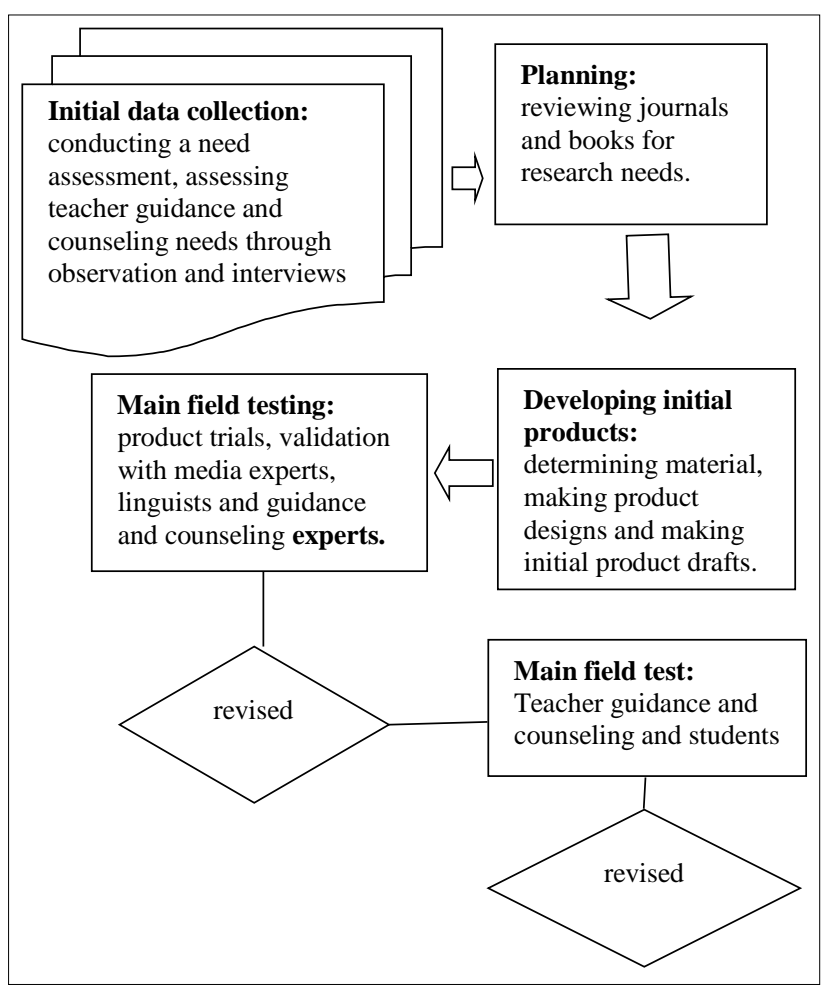

Figure 1. Development Procedure

The initial stages of this development begin with conducting a need assessment to find all information about the needs in the field and all the problems faced by BK teachers and students. The problem found is the unavailability of media to help students understand career planning. The second stage is the planning stage, studying theories or concepts related to media that can help students understand career planning. This stage provides an overview of the use of applications spinning as an information service to enhance students' knowledge about career planning. The next stage, entering the product development stage, is carried out by making application. Spinning which contains the rational of making an application, core competencies, basic competencies, material that contains an explanation of a career.

The next stage is a trial that is conducted an assessment by media experts, Language and $\mathrm{BK}$ to determine the level of attractiveness of the product format and contents, ease of contents and menus on the application spinning and the usefulness of the application spinning. After the assessment, the researchers revised the product in accordance with expert input. The sixth phase is the main field trials targeting BK teachers and students to find out the effectiveness, attractiveness of the ease and benefits of applications spinning to increase students' knowledge of career planning. The final stage is a product revision of the shortcomings and input from students.

In the expert assessment the acceptability scale is used which is developed based on the acceptance aspect of a product that has been determined by The Joint Committee On Standards For Educational Evaluation. The analysis used in expert judgment is the tabulation of the appraiser's or agreement inter-rater agreement.

\section{Result}

\section{RESULTS \& DISCUSSION}

In this research development, the prototype produced is media spinning as an information service to improve the career planning of high school students in Lampung, which meets the acceptability aspects of content and format, namely attractiveness, convenience and usefulness. The initial appearance of this media is the homepage to start the application, the second part shows the types of professions that are categorized in the social, business, realistic, conventional, artistic and intellectual fields. This field written on spinning will rotate when we click the play button. Other menus after spinning is played are the types of professions that are appropriate to the field, and this menu will provide information about various professions.

The results of the acceptance tests of experts and users showed an average percentage of $86 \%$ which was in a very good range. This shows that media spinning as an information service to improve students' career selection meets the criteria of acceptability of experts and users theoretically and practically, so that it can be used in the service delivery process in the career field. The input from experts that can be used as a benchmark for improvement is explained in Table 1 below.

Table 1. Members and prospects for user improvement feedback

\begin{tabular}{lll}
\multirow{2}{*}{ Media expert } & Before & After \\
\cline { 2 - 3 } & $\begin{array}{l}\text { On the } \\
\text { homepage, the } \\
\text { layout is less } \\
\text { attractive }\end{array}$ & $\begin{array}{l}\text { Layouts are } \\
\text { replaced with } \\
\text { bright colors to } \\
\text { make them more } \\
\text { attractive. }\end{array}$ \\
\cline { 2 - 3 } Linguist & $\begin{array}{l}\text { The language } \\
\text { used is easy to } \\
\text { understand. }\end{array}$ & - \\
\cline { 2 - 3 } $\begin{array}{l}\text { Expert guidance } \\
\text { and counseling }\end{array}$ & $\begin{array}{l}\text { Enrich in a } \\
\text { profession that } \\
\text { complies with }\end{array}$ & $\begin{array}{l}\text { Types of } \\
\text { professions are } \\
\text { categorized } \\
\text { according to the } \\
\text { needs and }\end{array}$ \\
& RI 4.0 &
\end{tabular}




\begin{tabular}{ll}
\hline & $\begin{array}{l}\text { development of } \\
\text { the times. }\end{array}$ \\
\hline $\begin{array}{l}\text { Display images } \\
\text { that are less } \\
\text { attractive }\end{array}$ & $\begin{array}{l}\text { Image corrected } \\
\text { as user entered. }\end{array}$ \\
\hline $\begin{array}{l}\text { Add a user } \\
\text { history menu } \\
\text { that can be } \\
\text { opened by } \\
\text { guidance and } \\
\text { counseling } \\
\text { teachers to help } \\
\text { in service } \\
\text { delivery. }\end{array}$ \\
\hline
\end{tabular}

Research conducted on career planning through media spinning to improve career planning. It is known that the main problem that hinders students in career planning is the lack of use of the media used during the career guidance process. Due to the development of-based guidance counseling media spinning. The results of the research and development of media are spinning described based on the Borg and Gall steps. Data on the results of each stage of the research procedure are based on the following development steps:

1. Results of Analysis of Potential Problems

After knowing the problems that occur in schools through observation and interviews with educators, the authors conclude that the main problem that hinders students in career planning is the absence of media used during the career guidance process.

2. Data

Collection Information gathering is done after analyzing problems at school. The absence of counseling guidance media used in the guidance process and also the lack of enthusiasm of students at the time of the guidance process is a major factor in the need for media.

3. Product Design

After the potential problem steps and data collection are completed, next the design of-based media spinning as a tool in career planning for class XI students, a source of reference for media development using applications spinning obtained by researchers to be a reference material for making media counseling guidance.

4. Product Validation Product

validation is intended to require expert judgment, namely material experts and media experts.

5. Media Expert

Validation Product validation is intended to request expert judgment, namely media expert.

6. Product

Trial Trials conducted by researchers are small group trials and large group trials.

\section{Discussion}

Career planning is a process in deciding career goals to be achieved and designing how these goals can be achieved. Career planning in adolescents is characterized by various activities in life such as learning about career information, discussing related career planning to adults, actively participating in extracurricular activities or taking courses or training that is preferred [7]. This is consistent with Dillard's opinion [8] which states that career planning is a process of achieving career goals. In career planning there are several factors that influence the selection of individual careers, namely external factors, such as family, race, socio-economic level, technology, labor market. The internal factors such as talent, interest, intelligence, personality [9]

Based on these factors career planning will arise and develop if it gets encouragement from family, economic conditions, technology and a supportive job market that supports the development of career planning. In addition, internal factors such as interests, talents, and patterns of interaction with others also determine the formation of it. This is consistent with the results of research by Person and Wilson [10] which states that the factors that influence career planning are abilities, interests and achievements. The explanation of the three factors is as follows.

1. Ability, namely confidence associated with outstanding talent in a field of cognitive business, the field of skills, or the field of art. Once formed an ability can become a provision that allows to enter various fields of work or when entering tertiary level in a particular field. Someone who has a prominent ability or talent usually has a fairly high level of confidence in actualizing himself.

2. Interest, which is a rather settled tendency for someone to feel interested in a particular field and feel.

To improve students' career planning skills, information services are needed by using new media. According to Ely [11], said that "the media when understood in general is human, material, or event that can help students in gaining knowledge, skills, or attitudes". In this case the teacher, the material provided is one of the media that can be used.

In providing guidance and counseling information services it is necessary to use media in order to maximize students in receiving the information provided. One of the media that can be used is media spinning. Media Spinning is a game in the form of wheels and question cards [12]. In media spinning there are several ways in its implementation. Games Spinning can be said with a game ball spin, a collection of cards containing questions about career material to increase the interest and motivation of students so that they can be actively involved in participating in career planning activities [12].

To anticipate this, in this study the steps used were 7 steps from Borg and Gall. Spinning is a counseling guidance media that consists of a series of materials, pictures, videos arranged into a spinning complete. This is 
in line with Aziz's research [12] which states that the use of media spinning on career planning has a high level of validity. The stages carried out are:

1. The first stage of potential and problems namely the absence of media as a tool for the guidance process in schools.

2. The second stage of gathering information is done after analyzing the problem at school. The absence of media used in the guidance process and also the lack of enthusiasm of the students at the time of the guidance process is a major factor in the need for the media as a tool in conducting career guidance.

3. The third stage is product design. At this stage the preparation is carried out in the form of media and instrument design. The instruments include a questionnaire for media experts and material experts as well as a questionnaire for students' responses to the use of media.

4. The fourth stage is the product validation from the material expert judgment and the media expert evaluation.

5. The fifth stage is product revision, after the media is revised and declared valid to be simulated, then the student participants are tyouted.

6. This stage is the sixth stage of product testing. In the seventh stage there was no revision because based on small-scale product trials and large-scale media spinning based on career planning it was already very interesting and feasible to be used in class XI of SMA YP UNILA Bandar Lampung.

\section{IV.CONCLUSION}

Career planning is a process in deciding career goals to be achieved and designing how they will be achieved. One of the tasks of adolescent development is to be able to determine and plan for future careers. To realize this, information about career planning is needed. Provision of information can be effective if used by using media. One of the media that can be used is media spinning. From the results of previous studies, spinning technique can be applied to learning for archival materials. For further research it is recommended to be able to prove the effectiveness of spinning in improving student career planning.

\section{REFERENCES}

[1] Adiputra, Sofwan., "Penggunaan Teknik Modeling Terhadap Sutrisno, B. "Perencanaan Karir Siswa Smk (Sebuah Model Berbasis Pengembangan Soft-Skill”. Jurnal Varia Pendidikan, Vol. 25. No. 1, Juni 2013. http://journals.ums.ac.id/index.php/varidika/article/view/714/44

[2] Super, D. E., Crites, J. O., Hummel, R. C., Moser, H. P., Overstreet, P. L., \& Warnath, C. F. "Vocational development: A framework for research". New York: Bureau of Publications, Teachers College, Columbia University. 1957.

[3] Galuh Hartinah. "Perkembangan model layanan informasi karir berbasis lift skills untuk meningkatkan pemahaman perencanaan karir siswa SMA”, Universitas Negeri Semarang, 2015.

[4] Pujiastuti, F. "The Use of Career Information Services to Increase Student Understanding in Career Decision Making”. Jurnal Penelitian Pendidikan. 2018.

[5] Atmaja Tandar Twi. "Upaya Meningkatkan Perencanaan Karir Siswa Melalui Bimbingan Karir dengan Penggunaan Media Modul". PSIKOPEDAGOGIA. Universitas Ahmad Dahlan. Vol. 3, No.2. ISSN: 2301-6167. 2014.

[6] Gall, M. D., Gall, J. P., \& Borg, W. R. "Educational Research. Educational Research: An Introduction".2003.

[7] Adiputra, Sofwan. "Penggunaan Teknik Modeling Terhadap Perencanaan Karir Siswa”. Jurnal Fokus Konseling Volume 1 No. 1, Januari 2015 Hlm. 45-56. http://ejournal.stkipmpringsewulpg.ac.id/index.php/fokusc

[8] Dillard. J. M. "Lifelong Career Planing". Ohio: A bell \& Howell Company Columbus. 1985.

[9] S. A. Lailly Nurillah, "Program Bimbingan Karir Untuk Meningkatkan Kematangan Karir Mahasiswa". Universitas Pendidikan Indonesia, 2017.

[10] Komara Indra Bangkit. "Hubungan antara Kepercayaan Diri dengan Prestasi Belajar dan Perencanaan Karir Siswa”. PSIKOPEDAGOGIA: Vol 5 No 1.2017 .

[11] Wahyunica, Widhya Dwi Oktaviani \& Rosi Brillian. "Pengembangan Media Pembelajaran Permainan Spinning Wheel Pada Kompetensi Dasar Alat Dan Bahan Kearsipan Siswa Kelas X APK 1 Di SMK PGRI 2 Sidoarjo".2017. https://jurnalmahasiswa.unesa.ac.id/index.php/jpap/article/view/216 83.

[12] Aziz, Abdul. "Media Spinning Sebagai Layanan Informasi Untuk Meningkatkan Kemampuan Perencanaan Karir Peserta Didik Kelas I SMA YP Unila Bandar Lampung". Skripsi. UIN Raden Intan Lampung. 2019. 